\title{
Scope Validity of the Graph Drawing and Interpretation Skill Checklist
}

\author{
Bülent Aksoy ${ }^{1} \&$ Remzi Namal ${ }^{1}$ \\ ${ }^{1}$ Gazi Educational Faculty, Gazi University, Ankara, Turkey \\ Correspondence: Bülent Aksoy, Gazi Educational Faculty, Gazi University, Ankara, Turkey.
}

Received: September 8, 2019

Accepted: October 20, $2019 \quad$ Online Published: December 30, 2019

doi:10.5539/ies.v13n1p76

URL: https://doi.org/10.5539/ies.v13n1p76

\begin{abstract}
The aim of this study is to determine the scope validity of the graph drawing interpretation skill checklist that can be used in social studies teaching. The literature review was made while the draft skill checklist was prepared at first. There have generally been some graph drawing and interpretation skill checklist studies at secondary and higher education levels. However, a graph drawing and interpretation skill checklist prepared for the social studies course at the primary education level has not been found. In the next step, items of the graph drawing and interpretation skill checklist were prepared. It has been benefitted from the literature on the graph drawing and interpretation for this. Attention has been paid to the preparation of items that assess the graph drawing and interpretation skill at the elementary education level. The scope validity of the items was analyzed employing the technique developed by Lawshe (1975) based on assessments of 10 specialists in their field. Analysis results show that the scope validity ration of the skill checklist was sufficient, thereby being workable in assessing the graph drawing and interpretation skill in social studies teaching.
\end{abstract}

Keywords: graphs, graph drawing, graph interpretation

\section{Introduction}

Figures that help us to understand and describe are called graphs. Graphs are the presentation of information or statistical data in the form of the figure. In addition to having different meanings in different disciplines, the concepts such as diagram, shape, histogram, polygon, curve, pictures, sketch and plan are used in the same sense as graphs. In other words, they are interchangeable concepts. Each of these concepts conveys different meanings for different branches of science. Graphs, charts, and maps are generally used instead of graphs in English sources (Arıkan, 2003).

The graphs make data editing, interpretation and presentation easy (Beichner, 1994; McKenzie \& Padilla, 1984). They are generally used to show mathematical functions, to present data collecting from social and life sciences and to indicate the scientific theories in printed media and textbooks related to in-class and out-of-class activities. In addition to these, they play an important role in visual learning (Shah \& Hoeffner, 2002). The graphs that are in particular useful for simplifying a large amount of information or illustrating the state of two or more interconnected and related things have a practical use as they do not include too much detail. The graphs and their use are also effective in our daily life as they help to solve the real problems and to present by visualizing the interrelationships between objects (Huang \& Eades, 2005).

Scientific, economic and demograph and other forms of information have today been shown quantitatively by using graphs mostly. For this reason, the graphs are important tools that enable us to understand the phenomenon in quantitative terms. Furthermore, the graphs serve as analytical tools for presenting the real observations and detecting the pattern and connection. Graph-based knowledge representation is a powerful way to reduce the emergent complexity and to concretize relationships between data (Tairab \& Al Naqbi, 2004).

Many types of graphs are defined depending on their use in different fields (Moline, 1995; Gillespie, 1993; Tufte, 1983; Arıkan, 2003). However, the most known and commonly used types of graphs are pie, column and line charts (Parker, 2001 cited in Yazıc1, 2006).

Social studies class is a course that involves intense visual-based learning by its content and nature. The use of visual materials in social studies teaching eliminates the monotony of the learning environment and provides permanent learning (Yazıcı, 2006; Ulusoy \& Gülüm, 2009). Many different kinds of visual materials (Öztürk \& Dilek, 2007) can be used in a social studies course. One of these visual materials is graphs. 
Different types of graphs can be used in many domains of learning and in different subjects. All kinds of graphs can be used depending on the content of subjects in teaching the social studies class (Yanpar-Yelken, 2015). One of the most noteworthy cases as to graphs' place in the social studies class is the graph types specific to social studies such as population pyramids, climate diagrams. All kinds of graphs can be used for teaching the social studies course depending on the content of the subjects. The graphs use is a skill area. Graphs uses as graph drawing and interpretation in teaching social studies.

Teaching skills is not like teaching information and is different from it. In the skill teaching, the basic information about the skill is firstly given, the purpose of the skill is explained and then the techniques related to the skill are taught through making different applications. Students need to develop a skill by applying this information so that they understand and envisage the information presented. Finally, students should be guided and supported to use the skills they have learned in different situations (Güneş, 2012).

Teaching skill continues to exist as a phenomenon that increases its importance day by day in today's world as a process that is aimed to continue throughout life. As an inevitable result of this situation, teaching skill will hold more place in the curricula of countries itself.

Teaching skill is the activities that the individual is foreseen able to do or has done depending on the competencies he/she has. Social studies class by its nature is a course in which skills have an important place. Great emphasis was placed on the skills in both the 2005 program and the 2018 program. Skill in drawing and interpreting graphs is included also in both programs (directly and indirectly). The goal of the fundamental philosophy of the social studies curriculum (2018) is to raise individuals who are capable of thinking innovatively and solving problems, know the ways to reach accurate information and can think analytically. The use of graphs in social studies teaching also contributes to the realization of these goals involved in the fundamental philosophy of the social studies curriculum. Because the skills related to the graph improve the skill in analyzing and interpreting, and provide the learners with the opportunity to gain various perspectives. In this context, the skill at drawing and interpreting graphs in the social studies teaching contributes to the fundamental philosophy of the social studies curriculum.

This study aims to determine the scope validity of the graph drawing and interpreting skill checklist which is created to measure the ability to draw and interpret the graph which can be used in social studies teaching.

\section{Method}

\subsection{Study Group}

This research is a scale development study. The study group of the research consisted of 10 experts who have similar studies with subject determining according to Lawshe technique, have enough knowledge and equipment and can take the time to evaluate.

\subsection{Writing of Graph Drawing and Interpretation Skill Checklist Items}

In order to write the items that will be included in the graph drawing and interpretation skill checklist, the literature and social studies curriculum related to graph drawing and interpretation are examined first of all. Graph drawing and interpretation skill checklist consisting of a total of 16 items, of which the first 10 are about the graph drawing and the last 6 about the graph interpretation, was prepared. The item writing was completed with the opinions of the experts with similar studies.

\subsection{Data Collection}

The form prepared according to Lawshe technique has been submitted to the experts in order to evaluate the graph drawing and interpretation skill checklist developed to measure the graph drawing and interpretation skill in social studies teaching.

\subsection{Data Analysis}

The assessment forms gathered from the experts were combined and the Lawshe technique was applied to determine the scope validity. The Lawshe technique is used in the scale development studies based on the theoretical process in cases where there is no trial practice. It consists of six stages: These stages are:

- Establishment of a group of field experts

- Preparation of candidate scale forms

- Assessment of expert opinions

- Calculation of the scope validity ratios for items 
- Determination of scope validity indices related to the scale.

- $\quad$ Establishment of final form according to scope validity ratios and scope validity indices (Yurdugül, 2005).

Stage I: The group of field experts should consist of at least 5, maximum of 40 experts.

Stage II: The items in the form prepared for the experts are graded as tripartite according to the criteria of "item necessary", "item useful but insufficient" and "item unnecessary".

Stage III: The aggregate expert opinions are collected in a single form to be graded.

Stage IV: How many experts have approved the options of each item is determined in total.

Scope validity ratio, which is expressed as the ratio of the total number of experts who have responded positively (required) for each item to the total number of experts minus 1, has been calculated.

$$
\mathrm{KGO}=\frac{N G}{N / 2}-1
$$

$N G$ : Number of experts who say the item "necessary"

$N$ : Total number of experts participating in the research

If half of the experts gave the answer "necessary", $\mathrm{KGO}=0$; if more than half of the experts gave the answer "necessary", $\mathrm{KGO}>0$; if less than half of the experts gave the answer "necessary", $\mathrm{KGO}<0$.

Stage V: The scope validity index (KGI) was calculated using the mean of KGO of the remaining items after excluding the items whose KGO obtained for each item were statistically insignificant. KGI should be greater than KGO (scope validity criterion) so that the scale can be valid.

The scope validity criterion, which is obtained according to the principles of the standard normal distribution, is useful for evaluating if whether the item is statistically significant.

Stage VI: If the scope validity related to the entire scale is sufficient, the final form is created (Yurdugül, 2005).

\section{Findings}

\subsection{Scope Validity Ratios}

Table 1 shows the scope validity ratios of the items included in the graph drawing and interpretation skill checklist.

Table 1. The scope validity ratios of the graph drawing and interpretation skill checklist (KGO)

\begin{tabular}{ccccc}
\hline Item & Necessary & Useful/Insufficient & Unnecessary & KGO \\
\hline 1 & 10 & 0 & 0 & 1 \\
2 & 10 & 0 & 0 & 1 \\
3 & 10 & 0 & 0 & 1 \\
4 & 10 & 0 & 0 & 1 \\
5 & 10 & 0 & 0 & 1 \\
6 & 10 & 0 & 0 & 1 \\
7 & 10 & 0 & 0 & 1 \\
8 & 9 & 1 & 1 & 0.80 \\
9 & 9 & 1 & 1 & 0.80 \\
10 & 8 & 2 & 0 & 0.60 \\
11 & 10 & 0 & 0 & 1 \\
12 & 9 & 1 & 1 & 0.80 \\
13 & 10 & 0 & 0 & 1 \\
14 & 10 & 0 & 0 & 1 \\
15 & 10 & 0 & 0 & 1 \\
16 & 10 & 0 & 0 & 1 \\
\hline
\end{tabular}

The scope validity ratios in Table 1 show that more than half of the experts gave the answer "necessary" to each item. If the KGO values are negative or zero, they are excluded. However, since each item in Table 1 is KGO $>0$, the items have a high scope validity ratio and there is no item to be excluded from the form. 


\subsection{Scope Validity Criterion}

The scope validity criterion, which is obtained according to the principles of the standard normal distribution, is useful for assessing if whether the item is statistically significant. A minimum value of KGO of the study group consisting of 10 experts at the significance level of $\alpha=0.05$ is considered as 0.62 (Veneziano \& Hooper, 1997, quoted by Yurdugül, 2005). The minimum values that should be according to some expert numbers are presented in Figure 1.

\begin{tabular}{|c|c|c|c|c|}
\hline Number of experts & Minimum value & & Number of experts & Minimum value \\
\hline 5 & 0.99 & & 13 & 0.54 \\
\hline 6 & 0.99 & & 14 & 0.51 \\
\hline 7 & 0.99 & & 15 & 0.49 \\
\hline 8 & 0.78 & 20 & 0.42 \\
\hline 9 & 0.75 & & 25 & 0.37 \\
\hline 10 & 0.62 & & 30 & 0.33 \\
\hline 11 & 0.59 & & 35 & 0.31 \\
\hline 12 & 0.56 & & $40+$ & 0.29 \\
\hline
\end{tabular}

Figure 1. Minimum values of KGO according to number of experts $(\alpha=0.05)$

As the study group consisted of 10 experts, the scope validity criterion should be a minimum of 0.62 according to the values shown in Figure 1.

\subsection{Scope Validity Index}

According to the scope validity ratios, there exists no item that is statistically insignificant among the items involved in the form. The mean of KGO of 16 items was $15 / 16=0.94$. The minimum significance level of scope validity criterion for a study group consisting of 10 experts was found to be 0.62 . Accordingly, as the scope validity criterion was 0.62 and the scope validity index was 0.94 (KGI>KGO), the scope validity of the assessment instrument created has been statistically significant. The values relating to the entire assessment instrument are shown in Table 2.

Table 2. Values relating to the entire assessment instrument

Number of experts: 10

\begin{tabular}{ccccc}
\hline Item & Necessary & Useful/Insufficient & Unnecessary & KGO \\
\hline 1 & 10 & 0 & 0 & 1 \\
2 & 10 & 0 & 0 & 1 \\
3 & 10 & 0 & 0 & 1 \\
4 & 10 & 0 & 0 & 1 \\
5 & 10 & 0 & 0 & 1 \\
6 & 10 & 0 & 0 & 1 \\
7 & 10 & 0 & 0 & 1 \\
8 & 9 & 1 & 1 & 0.80 \\
9 & 9 & 1 & 1 & 0.80 \\
10 & 8 & 2 & 0 & 0.60 \\
11 & 10 & 0 & 0 & 1 \\
12 & 9 & 1 & 1 & 0.80 \\
13 & 10 & 0 & 0 & 1 \\
14 & 10 & 0 & 0 & 1 \\
15 & 10 & 0 & 0 & 1 \\
16 & 10 & 0 & 0 & 1 \\
\hline
\end{tabular}

Scope validity criterion: 0.62

Scope validity index: 0.94 


\section{Results and Discussions}

The scope validity of the graph drawing and interpretation skill checklist, which is designed to evaluate the skill in drawing and interpreting the graph in social studies teaching, is examined in this study. As the graph drawing and interpretation skill checklist aims to assess at the level of primary education, the items are prepared according to the skill levels of primary education students. The first 10 items of the scale are related to drawing, while the last 6 items are related to interpretation. The findings obtained from expert opinions in the study show that the scope validity level of the graph drawing and -interpretation skill checklist was rather high as 0.94 . In this context, it can be asserted that the graph drawing and interpretation skill checklist is at the usable level.

Similar previous studies on the subject often involve those that are specific to a single chart type, and the majority of these are out of the field of social studies McKenzie and Padilla (1986), Taşar, İngeç, and Ünlü (2002), Tan and Temiz (2009), Oruç and Akgün (2010), Kaynar and Halat (2012), Yabanll, Yıldırım, and Günaydın (2013), Memnun (2013) and Erbilgin, Arıkan, and Yabanlı (2015), Ablak, (2017). Therefore, this study aims to fill the gap that had not been addressed in previous studies.

It is expected that since the assessment instrument developed within the scope of the study does not already exist in the literature, its compatibility with the curriculum would fill a great gap in the field. It has been considered that the graph drawing and interpretation skill checklist can be employed in both the social studies teaching and different fields, and will also be helpful for researchers and teachers working on the subject. Considering that our students involved in the internationally recognized evaluation programs such as PISA and TIMSS get low grades in the questions on graphs use, the number of studies to be carried out on the subject should be absolutely increased (MEB, 2013; MEB, 2016).

The relevant literature suggests that teachers and prospective teachers had insufficient comprehension and application skills related to graphs (Ball \& Mc Diarmid, 1990; Artega \& Batanero, 2011; Bayazıt, 2011; Gürgil, 2018). Therefore, the skill in drawing and interpreting graphs should be gained in the previous teaching stages without being left to the higher education stage.

\section{References}

Ablak, S. (2017). Sosyal bilgiler programındaki becerilere ilişkin ögrrenci algılarının incelenmesi (Doctoral thesis). Retrieved from https://tez.yok.gov.tr/UlusalTezMerkezi/tezSorguSonucYeni.jsp

Arıkan, R. (2003). Grafikler. Ankara: Asil.

Arteaga, P., \& Batanero, C. (2011). Relating graph semiotic complexity to graph comprehension in statistical graphs produced by prospective teachers. Proceedings of CERME (Vol. 7, pp. 725-734). Rzesow, Poland: University of Rzesow.

Ball, D. L., McDiarmid, W., Houston, W. R., \& Sikula, J. (1990). Handbook for research on teacher education. The subject-matter preparation of teachers. New York, NY: Macmillan.

Bayazıt, İ. (2011). Öğretmen adaylarının grafikleri anlama düzeyleri. Gaziantep Üniversitesi Sosyal Bilimler Dergisi, 10(4), 1325-1346.

Beichner, R. J. (1994). Testing student interpretation of kinematics graphs. American Journal of Physics, 62, 750-762. https://doi.org/10.1119/1.17449

Bell, A., Brekke, G., \& Swan, M. (1987). Misconceptions, conflict and discussion in the teaching of graphal interpretation. In J. D. Novak (Ed.), Proceedings of the second international seminar: Misconceptions and educational strategies in science and mathematics (Vol. 1. pp. 46-58). Ithaca, NY: Cornell University.

Erbilgin, E., Arıkan, S., \& Yabanlı, H. (2015). Çizgi grafiğini yorumlama ve oluşturma becerilerinin ölçülmesi. Kırşehir Eğitim Fakültesi Dergisi, 16(2), 43-61.

Gillespie, C. S. (1993). Reading graph displays: What teachers should know. Journal of Reading, 36(5), 350-354.

Güneş, F. (2012). Bologna süreci ile yükseköğretimde öngörülen beceri ve etkinlikler. Journal of Higher Education \& Science, 2(1), 1-9.

Gürgil, F. (2018). Table, graph and diagram interpretaion and preparation skills: social studies and geography teachers'practice and beliefs. Review of International Geographical Education Online, 8(3), 517-541. https://doi.org/10.33403/rigeo.505266

Huang, W., \& Eades, P. (2005, January). How people read graphs. Proceedings of the 2005 Asia-Pacific symposium on Information visualization (Vol. 45, pp. 51-58). Australian Computer Society, Inc. Retrieved 
from http://crpit.scem.westernsydney.edu.au/confpapers/CRPITV45Huang.pdf

Kaynar, Y., \& Halat, E. (2012). Sekizinci sinı ögrencilerinin sıklı tablosu okuma ve yorumlama becerilerinin incelenmesi. Paper presented at the X. National Congress on Science and Mathematics Education, Niğde, TR. Retrieved from http://kongre.nigde.edu.tr/xufbmek/dosyalar/tam_metin/pdf/2296-28_05_2012-18_18_ 14.pdf

Lawshe, C. H. (1975). A quantitative approach to content validity. Personnel psychology, 28(4), 563-575. https://doi.org/10.1111/j.1744-6570.1975.tb01393.x

Mckenzie, D. L., \& Padilla M. J. (1986). The construction and validation of test of graphing in science. Journal of Research in Science Teaching, 23(7), 1-9. https://doi.org/10.1002/tea.3660230702

McKenzie, D. L., \& Padilla, M. J. (1984). Effects of Laboratory Activities and Written Simulations on the Acquisition of Graphing Skills by Eighth Grade Students. Paper presented at the National Association for Research in Science Teaching. New Orleans, LA. Retrieved from https://eric.ed.gov/?id=ED244780

MEB. (2013). PISA ulusal ön raporu 2012. Retrieved from https://pisa.meb.gov.tr/wp-content/uploads/2013/12/ pisa2012-ulusal-on-raporu.pdf

MEB. (2016). PISA ulusal raporu 2015. Retrieved form https://pisa.meb.gov.tr/wp-content/uploads/2016/12/ PISA2015_Ulusal_Rapor1.pdf

Memnun, S. (2013). Ortaokul yedinci sınıf öğrencilerinin çizgi grafik okuma ve çizme becerilerinin incelenmesi. Turkish Studies, 8(12), 1153-1167. https://doi.org/10.7827/TurkishStudies.6026

Moline, S. (1995). I see what you mean: Children at work with visual information. York, ME: Stenhouse Publishing.

Oruç, Ş., \& Akgün, İ. H. (2010). İlköğretim sosyal bilgiler 7.sınıf öğrencilerinin grafik okuma becerisini kazanma düzeyleri. Uluslararası Avrasya Sosyal Bilimler Dergisi, 1(1), 51-58.

Öztürk, C., \& Dilek, D. (2007). Hayat bilgisi ve sosyal bilgiler öğretimi: Yapılandırmacı bir yaklaşım. Ankara: Pegem.

Shah, P., \& Hoeffner, J. (2002). Review of graph comprehension research: Implications for instruction. Educational Psychology Review, 14(1), 47-69. https://doi.org/10.1023/a:1013180410169

Tairab, H. H., \& Khalaf Al-Naqbi, A. K. (2004). How do secondary school science students interpret and construct scientific graphs? Journal of Biological Education, 38(3), 127-132. https://doi.org/10.1080/00219266.2004.9655920

Taşar, M. F., İngeç, Ş. K., \& Güneş, P. Ü. (2002). Grafik çizme ve anlama becerisinin saptanması. Retrieved from http://w3.gazi.edu.tr/ mftasar/publications/Grafik.pdf

Temiz, B. K., \& Tan, M. (2009). Grafik çizme becerilerinin control listesi ile ölçülmesi. Selçuk Üniversitesi Ahmet Keleşoğlu Eğitim Fakültesi Dergisi, 27, 71-83.

Tufte, E. R. (1983). The Visual Display of Quantitative Information. Retrieved from https://www.colorado.edu/geography/foote/maps/assign/reading/TufteCoversheet.pdf

Ulusoy, K., \& Gülüm, K. (2009). Sosyal bilgiler dersinde tarih ve coğrafya konuları işlenirken öğretmenlerin materyal kullanma durumları. Ahi Evran Üniversitesi Ĕgitim Fakültesi Dergisi, 10(2), 85-99.

Yabanlı, H., Yıldırım, B., \& Günaydın, Ö. (2017). Haritadan çizgi grafiğine. Araştırma Temelli Etkinlik Dergisi, $3(1), 12-19$.

Yanpar-Yelken, T. (2015). Öğretim teknolojileri ve material tasarımı. Ankara: Anı.

Yazici, K. (2006). Sosyal bilgilerde kullanılan görsel araçlar: Haritalar-küreler, resimler, tablolar ve grafikler. Selcuk Üniversitesi Sosyal Bilimler Enstitüsü Dergisi, 15, 651-662.

Yurdugül, H. (2005). Ölçek gelişstirme çalışmalarında kapsam geçerliği için kapsam geçerlik indekslerinin kullanilmast. Paper presented at the XIV. National Congress on Educational Sciences, Denizli, TR. Retrieved from http://yunus.hacettepe.edu.tr/ yurdugul/3/indir/PamukkaleBildiri.pdf 


\section{Appendix A}

\section{Graph Drawing and Interpretation Skill Checklist and Expert Assessment Form}

\section{Dear Expert,}

The assessment instrument submitted to your evaluation below aims to assess the graph drawing and interpretation skill. We request you to evaluate each item according to its purpose. If the item is suitable for assessing the specified feature clearly, it is "necessary", the item is within the scope of subject but if needed to be corrected, it is "useful/insufficient" (please indicate why it is insufficient, or the part required to be corrected) and if the item does not represent the specified feature, please mark the options "unnecessary". If any, please include the items you would like to add.

\begin{tabular}{|l|l|l|l|l|}
\hline No. & Skills & Necessary & Useful/sufficient & Unnecessary \\
\hline 1 & Uses material suitable for graph drawing & & & \\
\hline 2 & Recognizes the components of the graph (axis, circle) & & & \\
\hline 3 & May determine the type of graphs to be drawn using the data presented & & & \\
\hline 4 & $\begin{array}{l}\text { Follows the correct stages in graph-drawing depending on the type of } \\
\text { graph. }\end{array}$ & & & \\
\hline 5 & $\begin{array}{l}\text { May write the data to the relevant sections in the graph (horizontal and } \\
\text { vertical axis, slice) }\end{array}$ & & & \\
\hline 6 & May write the units or values of the data to the proper place & & & \\
\hline 7 & May carry out appropriate measurements to write data correctly. & & & \\
\hline 8 & May make a drawing according to the appropriate gap width and ratios & & & \\
\hline 9 & May draw the desired graph based on the data & & & \\
\hline 10 & $\begin{array}{l}\text { May draw a graph in another suitable graph type (May transform a graph } \\
\text { into another suitable graph type) }\end{array}$ & & & \\
\hline 11 & May write a graph title according to its content & & & \\
\hline 12 & May explain numerical data of graph with simple expressions & & \\
\hline 13 & May draw inferences from the data in the graphs & & & \\
\hline 14 & May make a prediction from the data in the graphs & & \\
\hline 15 & $\begin{array}{l}\text { May explain the relationship-pattern between variables by interpreting the } \\
\text { graph }\end{array}$ & & & \\
\hline 16 & $\begin{array}{l}\text { May make quantitative/proportional comparisons between the same or } \\
\text { different types of graphs }\end{array}$ & & & \\
\hline
\end{tabular}




\section{Appendix B}

Graph Drawing and Interpretation Skill Checklist

\begin{tabular}{|c|c|c|c|c|}
\hline No & Skills & $\begin{array}{l}\text { Yes } \\
(2)\end{array}$ & $\begin{array}{c}\text { Partially } \\
\text { (1) }\end{array}$ & $\begin{array}{l}\text { No } \\
(0)\end{array}$ \\
\hline 1 & Uses material suitable for graph drawing & & & \\
\hline 2 & Recognize the components of the graph (axis, circle) & & & \\
\hline 3 & May determine the type of graphs to be drawn using the data presented & & & \\
\hline 4 & Follows the correct stages in graph-drawing depending on the type of graph. & & & \\
\hline 5 & May write the data to the relevant sections in the graph (horizontal and vertical axis, slice) & & & \\
\hline 6 & May write the units or values of the data to the proper place & & & \\
\hline 7 & May carry out appropriate measurements to write data correctly & & & \\
\hline 8 & May make a drawing according to the appropriate gap width and ratios & & & \\
\hline 9 & May draw the desired graph based on the data & & & \\
\hline 10 & May draw a graph in another suitable graph type (May transform a graph into another suitable graph type) & & & \\
\hline 11 & May write a graph title according to its content & & & \\
\hline 12 & May explain numerical data of graph with simple expressions & & & \\
\hline 13 & May draw inferences from the data in the graphs & & & \\
\hline 14 & May make a prediction from the data in the graphs & & & \\
\hline 15 & May explain the relationship-pattern between variables by interpreting the graph & & & \\
\hline 16 & May make quantitative/proportional comparisons between the same or different types of graphs & & & \\
\hline
\end{tabular}

\section{Copyrights}

Copyright for this article is retained by the author(s), with first publication rights granted to the journal.

This is an open-access article distributed under the terms and conditions of the Creative Commons Attribution license (http://creativecommons.org/licenses/by/4.0/). 